\title{
Covid-19 Through Brazilian Courts: The Deserving and the Undeserving Vulnerable
}

\author{
Luciano Bottini Filho (i) \\ Lecturer, Sheffield Hallam University \\ Corresponding author: luciano.bottini2@gmail.com
}

(Received 03 May 2021; accepted 25 June 2021)

\begin{abstract}
Looking into these times of neoconservatism in Brazil, marked by a far-right agenda and populism, this Article explores the role of vulnerability (as a legal theory, a legal principle or factual consideration) in the litigation prompted by the pandemic in Brazil. The usages of vulnerability as a form of resistance to the denial of their identity and vulnerable condition show that vulnerability can take different forms through litigants and may have an independent meaning to what is defined in legal theory or law. This is most evident by the fact that litigants dispute government policies based on ideologies that contest their identities (and not merely their vulnerability). Four case studies substantiate this Article with lawsuits brought to higher courts by judicially active groups: prisoners, indigenous people, Afro-Brazilian ethnic communities and gig economy drivers. They are what I call "undeserving vulnerables", groups discriminated from a legally recognized vulnerable group through attacks to their identity.
\end{abstract}

Keywords: Covid-19; right to health; vulnerability theory; litigation; Brazil

Litigation under the right to health in Brazil has repeatedly raised questions of inequality and unfairness towards the less empowered. A common empirical finding is that it has produced a "Robinhood in reverse" effect, diverting resources from the poor to the wealthy able to file a lawsuit and seek highly costly treatments. ${ }^{1}$ Though the research on the profile of litigants and claims has been ongoing over the last twenty years and has produced some robust evidence for this interpretation, there is still much debate over whether such studies are representative of the whole population. ${ }^{2}$

These empirical controversies of whether litigation works for those in need remain important under the COVID-19 outbreak. The virus could not find a worse political moment in the country,

I am grateful to the reviewers for the helpful comments and, in particular, to Dr. Patrycja Dąbrowska-Kłosińska, Professor Keith Syrett, Dr. Stefano Angeleri, Mrs. Lisa Montel, and other participants of the Symposium “The Protection Of Human Rights In Infectious Disease Control: Lessons For Global Health Governance From A Comparison Of National Judicial Practice." Any errors and omissions are entirely mine.

Luciano Bottini Filho Ph.D. Candidate, Centre for Health, Law and Society, University of Bristol.

${ }^{1}$ See generally Ana Luiza Chieffi \& Rita Barradas Barata, Judicialização da Política Pública de Assistência Farmacêutica e Eqüidade, 25 CAD. SAúde Pública 1839-49 (2009); Octavio Luiz Motta Ferraz, Harming the Poor Through Social Rights Litigation: Lessons from Brazil, 89 TEX. L. REV. 1643 (2010).

${ }^{2}$ See, e.g., João Biehl, Mariana P. Socal, Varun Gauri, Debora Diniz, Marcelo Medeiros, Gabriela Rondon, \& Joseph J. Amon, Judicialization 2.0: Understanding Right-to-Health Litigation in Real Time, Glob. PuB. HeAlth 1-10 (2018); João Biehl, Joseph J. Amon, Mariana P. Socal, \& Adriana Petryna, Between the Court and the Clinic: Lawsuits for Medicines and the Right to Health in Brazil, Health Hum. Rights 18 (2012).

(C) The Author(s) 2021. Published by Cambridge University Press on behalf of the German Law Journal. This is an Open Access article, distributed under the terms of the Creative Commons Attribution licence (http://creativecommons.org/licenses/by/4.0/), which permits unrestricted re-use, distribution, and reproduction in any medium, provided the original work is properly cited. 
which has been led by President Jair Bolsonaro since 2019. President Bolsonaro, a skeptic of the virus threat, has often referred to minorities as victimists. ${ }^{3}$ When confronted by flawed government responses to COVID-19 such as in Brazil, a priority that springs to mind is the most vulnerable - though it is not always clear whom we refer to as vulnerable. Looking into these times of neoconservatism in Brazil, marked by a far-right agenda, populism, and hate speech towards marginalized classes, this Article explores the role of vulnerability - as a legal theory, a legal principle, or factual consideration-in the litigation prompted by the pandemic in Brazil. ${ }^{4}$

Three patterns of vulnerability usages are compared in this analysis: Those theorized by Martha Fineman, prescribed by law in Brazil, and claimed by litigants in the COVID-19 crisis. In her theory, Fineman opposes labeling groups in terms of race, ethnicity, and social class, in an attempt to set vulnerability apart from anti-discrimination law as a universal reality of all human beings. ${ }^{5}$ A vulnerability theory, as suggested by Herring, either presupposes a general state of vulnerability to all humans - as with Fineman's post-identity view-or, more limitedly, describes categories of vulnerable groups that must receive more State assistance and resources. ${ }^{6}$ This second approach is followed by the law in Brazil and sometimes is associated with international human rights law. ${ }^{7}$ Litigants, in turn, may bring claims regarding specific alleged types of vulnerability-instead of a category of a vulnerable group - not perfectly addressed by law but recognized by them as a discriminatory policy or even an ideological attack on their identity.

This Article evaluates the notion of vulnerability and identity in judicial cases over public health measures against COVID-19. With reference to selected cases brought to higher courts in Brazil in the pandemic, the argument is that vulnerability can be universal-as proposed by Fineman's view-but some claimants cannot separate their identity to their dispute against discriminatory policies, so a neutral or generic vulnerability theory is insufficient to address political or ideological discrimination directed at the identity of vulnerable groups. Bolsonaro's government waged an antidemocratic and military discourse "in a cultural war" against minorities and social rights, in a movement of antiblackness, backtracking human rights policies, and supporting police brutality. ${ }^{8}$

The attacked identities are key to the vulnerability in Brazil. At times a general principle may be preferred against stereotypes or expectations of vulnerable groups — such as an indigenous person who never lives in the city-but in certain areas vulnerability needs to be responsive to discrimination to targeted groups. These two facets of vulnerability are exemplified with four case studies of COVID-19 litigation concerning indigenous people, incarcerated persons, African-Brazilian ethnic groups, and gig economy workers.

These cases indicate a pattern of how vulnerable conditions are articulated by claimants and judges divided between the "deserving" and "undeserving" vulnerable, as their identity is

\footnotetext{
${ }^{3}$ Francisco Ortega \& Michael Orsini, Governing COVID-19 Without Government in Brazil: Ignorance, Neoliberal Authoritarianism, and the Collapse of Public Health Leadership, 15 Glob. Pub. Health 1257 1257-59 (2020); Igor Silva Campos, Vinicius Ferreira Aratani, Karina Baltor Cabral, Jean Ezequiel Limongi, \& Stefan Vilges de Oliveria, A Vulnerability Analysis for the Management of and Response to the COVID-19 Epidemic in the Second Most Populous State in Brazil, at 520-21 (2020), http://medrxiv.org/lookup/doi/10.1101/2020.07.20.20158345 (last visited Oct 8, 2020).

${ }^{4}$ Leila Bijos, Ethnic-Racial Discrimination in Brazil: Bolsonaro Era, 1 Rev. CientífiCA DisRuptiva 94, 94-115 (2019); Ana Garcia, Brazil Under Bolsonaro: Social Base, Agenda and Perspectives, 6 J. Glob. Faultuines 9, 65-66 (2021).

${ }^{5}$ Martha Albertson Fineman, Introducing Vulnerability, in Vulnerability and the Legal Organization OF WORK 1, 3-5 (Martha Albertson Fineman \& Jonathan W. Fineman eds., 2017).

${ }^{6}$ Jonathan Herring, Defining Vulnerability, in Vulnerable Adults and THe Law, 6-8 (2016).

${ }^{7}$ On international law and vulnerable groups, see INGRID NIFOSI-SUTTON, THE PROTECTION OF VULNERABLE GROUPS UNDER INTERNATIONAL HUMAN RIGHTS LAW (2017).

${ }^{8}$ Bijos, supra note 5, at 109; Antonio José Bacelar Da Silva \& Erika Robb Larkins, The Bolsonaro Election, Antiblackness, and Changing Race Relations in Brazil, 24 J. Latin American CARIBbean AnTHropology 893, 902-10 (2019); Jaime A Alves \& João Costa Vargas, The Spectre of Haiti: Structural Antiblackness, the Far-Right Backlash and the Fear of a Black Majority in Brazil, 41 Third World Q. 645 (2020); Michelle Morais de Sá e Silva, Once Upon a Time, a Human Rights Ally: The State and its Bureaucracy in Right-Wing Populist Brazil, 42 HuM. Rights Q. 646, 662-65 (2020); Garcia, supra note 5, at 65-66.
} 
questioned by State authorities and neoconservative ideology. The deserving group is the vulnerable group that squarely fits into an ideal of vulnerable population or recognized status of vulnerable group as provided by law. As this analysis shows, one form of underserving vulnerable derives from a conditionality or rule that segregates a subgroup from vulnerable categories - such as a criminal who is convicted for a highly socially unacceptable crime versus other criminal offenders.

The underserving is an expression of half-hearted concession to vulnerable groups, imposing restrictions to their identity as vulnerable persons. Another treatment differentiation is the one dispensed to a new category of individuals who were never regarded as an ordinary vulnerable population by law but now are suffering most with COVID-19-as educated middle-class men who migrated to unsecured jobs not covered by employment law in the gig economy.

Different from previous studies in health litigation in Brazil, this is not a pure description of claimants — who litigates — or actions brought to courts — what is litigated — and the effects of litigation on inequality. ${ }^{9}$ Generally, studies intend to identify the profile of litigants over access to medicine and in relation to lawsuits concerning only the right to health, in lower courts, through samples or other forms of statistical inferences. In contrast, the decisions in this Article are part of a narrative review through a qualitative selection of relevant case-law-convenience samplefrom the Brazilian constitutional court (Supremo Federal Court or STF) emerging from the context of COVID-19 and other higher specialized tribunals for federal legislation (Superior Tribunal de Justiça or STG), labor relations (Tribunal Superior do Trabalho or TST). The rationale of the qualitative selection of cases was either an explicit usage of the term "vulnerability" by judges and litigants or the existence of a legal provision alluding to vulnerability. As we will see, the Brazilian legal system adopts principles analogous to vulnerability groups in some areas. After a delimited review of procedures filed from January, 2020 to September, 2020, four case studies were identified, where identity and vulnerability are inter-related and employed as a litigation apparatus. They show how vulnerability in theory and law can be divorced from identity struggles.

This Article proceeds in three main sections. Section A focuses on the universality of vulnerability theory and how the pandemic in Brazil was not generally to traditionally vulnerable groups. Section B will sketch the general framework of vulnerability in Brazilian law, noting that it does not constitute a stand-alone principle and rather an indirect application through special constitutional provisions and sparse legislation. Section $\mathrm{C}$ will trace the jurisprudence of the highest courts of the four groups that claimed their vulnerability - as a matter of fact and law-but were not recognized as such by the State.

\section{A. Vulnerability Theory as a General Legal Principle}

At first sight, vulnerability theory, as devised by Fineman, may be appealing in relation to COVID-19 because it does not commit to identities or vulnerable groups; everyone is vulnerable by default and under the dependency of the State to a certain degree. ${ }^{10}$ Given the variable effect of COVID-19, using a general vulnerability principle_- pervasive, but also context-dependent-may be helpful to engender legal responsibility of the State for anyone affected in different ways for all

\footnotetext{
${ }^{9}$ See generally Daniel Wang, Can Litigation Promote Fainess in Healthcare: the Judicial Review of Rationing Decisions in Brazil and England (2013) (Ph.D. thesis, The London School of Economics and Political Science); Danielle da Costa Leite Borges, Individual Health Care Litigation in Brazil through a Different Lens: Strengthening Health Technology Assessment and New Models of Health Care Governance, 20 Health Hum. Rights 147 (2018); Tatiana S. Andia \& Everaldo Lamprea, Is the Judicialization of Health Care Bad for Equity? A Scoping Review, 18 InT'L J. Equity Health 1 (2019); Ricardo Eccard da Silva, Elisangela da Costa Lima, Maria Rita C. G. Novaes, \& Claudia G. S. Osorio-de-Castro, The High "Cost" of Experimental Drugs Obtained Through Health Litigation in Brazil, 11 Frontiers In Pharmacology 752 (2020).

${ }^{10}$ Martha Albertson Fineman, The Vulnerable Subject: Anchoring Equality in the Human Condition, 20 YALE J. L. \& FEMINISM 1, 1-23 (2008).
} 
forms of epidemiological risks. ${ }^{11}$ As proposed by Freeman, vulnerability is a human condition beyond identity, departing from a discrimination approach to formal equality, in a universalism that transcends categories such as race and class. ${ }^{12}$ This section argues that the post-identity stance of vulnerability theory is both helpful and limiting in the pandemic and while it can free policies of a set category of vulnerable groups, it can be misunderstood and dilute identity-based claims.

In brief, for Fineman's vulnerability theory, what distinguishes each person is the resources and effective capacity to endure adversity. Freeman argues for a "responsive State" to allocate resources according to the levels of resilience needed to compensate for the vulnerability strengthened by institutions and society. ${ }^{13}$ This view attempts to steer clear of identity concepts by referring to complexity-how different factors converge to each individual embodied or embedded forms of vulnerability - and particularity-how this complexity materializes individually. Complexity and particularity could be easily taken as identity, but Fineman wants to use vulnerability foremost as a universal principle.

This theory seems to be open or flexible to any intervention in a public health crisis, if the State must take action to ensure resilience without stereotypes of vulnerable groups. ${ }^{14}$ The better alternative, in this view, would have the State taking responsibility for resource needs independent of identities to achieve substantive equality, as an anti-discrimination approach based on identity is limited to formal equality. ${ }^{15}$

For instance, the experienced vulnerability in Brazil in the pandemic established itself beyond traditional demographic lines such as elderlies and indigenous people. To be clear, this does not downplay the point that the pandemic had severe consequences among other groups, as with the disproportionate mortality of pregnant black women. ${ }^{16}$ However, despite enjoying better health indicators than the black population, middle class, and highly qualified white Brazilians were "the new vulnerable persons" as they have come up against the considerable risk of unemployment and income loss. ${ }^{17}$

Another example of the lack of point of reference for who is vulnerable is the epidemiological trajectory of the virus. The outbreak officially fell upon Brazil in February 2020, in a manner that predicted the disparities between economic classes in a country listed as the ninth in the world in income inequalities. ${ }^{18}$ The initial concentration on high-income groups could be partly explained by the fact that testing and treatments were mostly accessible to this population. ${ }^{19}$ Statistics slowly started to suggest that the likelihood of death in low-income families was considerably higher than those in a better economic position, especially for pardos (persons self-identified as mixed black

\footnotetext{
${ }^{11}$ Fineman, supra note 6 , at 7-8.

${ }^{12}$ Martha Albertson Fineman, Beyond Identities: The Limits of an Antidiscrimination Approach to Equality 92 B.U. L. REV. $1713,1752-53$ (2012).

${ }^{13}$ Martha Albertson Fineman, The Vulnerable Subject and the Responsive State, 60 EMORY L. J. 251, 269-75 (2010). Martha Albertson Fineman, Beyond Equality and Discrimination, 73 SMU L. REv. ForUm 51, 57-61 (2020).

${ }^{14}$ Osamudia R. James, Valuing Identity, 102 MinN. L. Rev. 127, 164-65 (2017).

${ }^{15}$ Fineman, supra note 14.

${ }^{16}$ Victor Santana Santos, Adriano Antunes Souza Araújo, Jarbas Ribeiro de Oliveira, Lucindo José Quintans-Júnior, \& Paulo Ricardo Martins-Filho, COVID-19 Mortality Among Indigenous People in Brazil: A Nationwide Register-Based Study, J. PuB. HeAlth (2020), https://doi.org/10.1093/pubmed/fdaal76 (last visited Oct. 29, 2020).

${ }^{17}$ Ian Prates \& Rogerio Jeronimo Barbosa, Políticas Públicas e as Respostasda Sociedade, In the crisis, black men and black women are the most vulnerable. But "new vulnerable" appear, white men and white women in non-essential services, (Apr. 24, 2020), https://redepesquisasolidaria.org/nao-categorizado/na-crise-homens-negros-e-mulheres-negras-sao-os-mais-vulneraveismas-surgem-novos-vulneraveis-homens-brancos-e-mulheres-brancas-em-servicos-nao-essenciais/ (last visited Oct. 1, 2020).

${ }^{18}$ The WORLD BANK, Gini Index, https://data.worldbank.org/indicator/SI.POV.GINI?end=2019\&most_recent_value_ desc $=$ true\&start $=2019 \&$ view $=$ bar (last visited May 2, 2021).

${ }^{19}$ Debora de Souza Santos, Mariane de Oliveira Menezes, Carla Betina Andreucci, Marcos Nakamura-Pereira, Roxana Knobel, Leila Katz, Heloisa de Oliveira Salgado, Melania Maria Ramos de Amorim \& Maira L. S. Takemoto, Disproportionate Impact of Coronavirus Disease 2019 (COVID-19) Among Pregnant and Postpartum Black Women in Brazil Through Structural Racism Lens, 72 CliniCAL InfECTIOUS DisEASES 1066, 14 (2020).
} 
and white) and blacks, yet the level of hospitalization is significantly lower in regions with less economic development. ${ }^{20}$

At first, the virus was brought by upper-class travelers returning from Europe, but then, the earliest death recorded involved a domestic worker infected by an employer, who on return from abroad did self-isolate after the diagnosis. ${ }^{21}$ Several other situations were confirmed where affluent individuals, despite being aware of their infection, did not send home domestic workers and did not take precautions to avoid transmission elsewhere. ${ }^{22}$ Once the virus found its way to other sections of society, by community transmission, the disease became less associated with the rich, and the poor became the victims. This trend has been even more acute within demographics such as indigenous people and black minorities, which were suddenly struck by the virus under a government hostile to identity inclusiveness.

Therefore, the downside to the flexibility and generalization of Fineman's theory to non-vulnerable groups is that it does not address the political assault on some identities and social positions by the State in moments of crisis, as with COVID-19 in Brazil. Vulnerability theory is criticized for negating the fact that identity is determinant to those subjected to the politics of hate-negative social perception, prejudice, racism, or xenophobia underpin a strand of vulnerability that cannot be universal. ${ }^{23}$ Oliviero notes that vulnerability is also "perpetrated through identity-based forms of marginalization" and instead of only stigmatizing, it can have a political meaning in unifying groups and promote resilience against universal and dominant categories of identity-such as whiteness and masculinity. ${ }^{24}$

Additionally, while vulnerability can be universal, a hostile environment openly targets minorities, hated groups, and whoever seems dependent upon State regulation, such as workers. In this example, State hostility is caused by the liberalization of work relations - as an undesired economic burden-and technological changes that have led to the precarity of workers' rights, which denied their legal status and potentialized their vulnerability with COVID-19. ${ }^{25}$

As the case studies will show, for those identifiable vulnerable groups, there is a political dimension connected to their identities and social status because persecuting some individuals is part of a political agenda to deny vulnerability and remove the dependency on the State. In contrast to the "universalist turn" in American legal scholarship, which recommends strategic universal claims without using specific identities, litigants in Brazil may have a strong sense of belonging to their class or cultural group. ${ }^{26}$ This litigation is a form of "identity resilience" and the evidence of vulnerability presented in courts attempts to reclaim their identity rejected by the State. In practice, it is difficult to separate vulnerability from identity, particularly when there is a clear sense of

\footnotetext{
${ }^{20}$ Pedro Baqui, Ioana Bica, Valerio Marra, Ari Ercole, \& Mihaela van der Schaar, Ethnic and Regional Variations in Hospital Mortality from COVID-19 in Brazil: A Cross-Sectional Observational Study, 8 LANCET Glob. HeAlth 1018, 1022 (2020).

${ }^{21}$ Alfonso J. Rodriguez-Morales, Viviana Gallego, Juan Pablo Escalera-Antezana, Claudio A Méndez, Lysien I Zambrano, Carlos Franco-Paredes, Jose A Suárez, Hernan D Rodriguez-Enciso, Graciela Josefina Balbin-Ramon, Eduardo Savio-Larriera, Alejandro Risquez \& Sergio Cimerman, COVID-19 in Latin America: The Implications of the First Confirmed Case in Brazil, 35 Travel Medicine InfeCtious Disease 101613, 1-2 (2020).

${ }^{22}$ Luciana Brito, The Hand of Cleanliness: Black Women and the Politics of Domestic Work During the Coronavirus Crisis (2020), https://www.citeblackwomencollective.org/our-blog/the-hand-of-cleanliness-black-women-and-the-politics-of-domesticwork-during-the-coronavirus-crisis-by-luciana-brito-phd (last visited Oct. 1, 2020).

${ }^{23}$ Frank Rudy Cooper, Always Already Suspect: Revising Vulnerability Theory, 93 N.C. L. REv. 42, 363-73; James, supra note 15 , at $166-68$.

${ }^{24}$ Katie Oliviero, Vulnerability Politics: The Uses and Abuses of Precarity in Political Debate 30-32 (2018).

${ }^{25}$ Rebecca E. Zietlow, The New Peonage: Liberty and Precarity for Workers in the Gig Economy, 55 WAKE FOREST L. REV. 57, 110-133 (2020).

${ }^{26}$ Charlotte S. Alexander \& Zev J. Eigent, Post-Racial Hydraulics: The Hidden Dangers of The Universal Turn, 91 N.Y.U. L. REV. 59, 17-22 (2015).
} 
common identity within those groups - for example, the growth of peasant's rights or the association of marginalized individuals in gangs. ${ }^{27}$

\section{B. Vulnerability in the Brazilian Law}

Having described vulnerability theory as a post-identity and universalist approach, this section considers vulnerability as prescribed by law in Brazil. While identity should be recognized in addressing vulnerability, establishing vulnerability solely through a category of individuals is also troublesome with COVID-19. This section explains how diffuse and fragmentary the development of the Brazilian vulnerability framework in legislation is, which can cause inconsistency in interpretation of vulnerabilities in a pandemic.

As opposed to a general theory of vulnerability, Brazilian law has a fragmented list of vulnerable groups, found everywhere, but not in a specific place in law. Such an approach is common in other jurisdictions, where the term vulnerability does not correspond to Fineman's theory but an official list of vulnerable groups. ${ }^{28}$ In Brazil, vulnerability is not an established interpretative criterion as may be in use at some courts - as in South Africa for example-by giving attention to the worseoff to determine the reasonableness of a policy in socioeconomic rights. ${ }^{29}$ Neither do judges refer to a general rule to prioritize resources to the most vulnerable in rights implementation, a position defended by some in international law. ${ }^{30}$

To begin, the Brazilian legislation suffers from great terminological imprecision of what vulnerability recognized in law means. In 2019, legislators inspired by the conservative and neoliberal climate in Brazil, adopted the "Declaration of the Rights of Economic Freedom," which among its principles include that of "the recognition of the vulnerability of the private man against the State" to be applied to businessmen and entrepreneurs. ${ }^{31}$ In the São Paulo Court of Appeal, at least sixty-six procedures were brought to the Court regarding public law matters in which vulnerability and COVID-19 have been cited nominally. ${ }^{32}$ Some business owners brought legal actions requesting a payment holiday for their financial obligations during the crisis. The court did not engage with the issue of vulnerability of businessmen or employees - the only nominal allusion to vulnerability was a quotation of the law that excepts some economic activities and services of the lockdown. ${ }^{33}$

Normally, though, the vulnerability in Brazilian law refers often to consumer and worker rights. ${ }^{34}$ Vulnerability is somewhat predominant in the Brazilian Consumer Code, as an internal

\footnotetext{
${ }^{27}$ Lua Kamil Yuille, Manufacturing Resilience on the Margins: Street Gangs, Property, \& Vulnerability Theory, 123 PENN State L. ReV. 477 (2019).

${ }^{28}$ Roxanna Dehaghani, Interrogating Vulnerability: Reframing the Vulnerable Suspect in Police Custody, 30 SoC. \& LEGAL STUD. 251, 252-56 (2021).

${ }^{29}$ Katharine G. Young, Proportionality, Reasonableness, and Economic and Social Rights, in ProporTIONALITY 248-72, 252-55. (Vicki C. Jackson \& Mark Tushnet eds., 2017).

${ }^{30}$ Camila Teixeira, Priority, Agency and Cooperation: How International Human Rights Law Helps Fulfil the Economic and Social Rights of the Most Vulnerable, 24 INT. J. HuM. RigHTS 1031, 1035-40 (2019).

${ }^{31}$ Lei No. 13.874, de 24 de Setembro de 2019, (Braz.).

${ }^{32}$ This sample was taken from decisions selected from the jurisprudence database of the Sao Paulo State Court (Tribunal de Justica de Sao Paulo, TJ-SP), the largest State court in the country. Two key terms were entered: "Vulnerability" and "Covid19," in Portuguese - with the synonymous results enabled. The search was further narrowed by decisions making reference to COVID-19 in their summary to ensure that all judgments are made in regard to the pandemic and separated into specialized chambers to cover administrative law and civil law. Information retrieved is updated until October 30, 2020. TRIBUNAL DE JUSTIÇA DE SÃo PAUlo, https://esaj.tjsp.jus.br/cjsg/resultadoCompleta.do

${ }^{33}$ TJ-SP Ap. Civ. No. 1032778-36.2018.8.26.0564, Relator: Leonel Costa, 30.06.2020, 8th Câmara de Direito Público, 30.06.2020 (Braz.).

${ }^{34}$ See e.g., TJ-RJ Ap. Civ. No. 0040072-24.2020.8.21.7000, Relator: Carlos Cini Marchionatti, 17.06.2020, Vigésima Câmara Cível, 29.09.2020 (Braz.) (A bank costumer was granted a clause revision to reduce the interest payments, for which one of the reasons was "the private person vulnerability.").
} 
overarching principle. ${ }^{35}$ In the Criminal Code, Article 217-A includes a category of a sexual offense committed against those under fourteen years old or incapable to provide consent, where culpability persists regardless of victim consent, in a felony denominated "rape of vulnerable person." ${ }^{36}$ Similarly, labor law in Brazil embraces the presumption of vulnerability by providing workers with less costly and technically onerous procedures to reflect an imbalance in economic powers. ${ }^{37}$ Employment claims have a process of their own and rely on principles such as in dubio pro labore or worker protection common to Latin American jurisdictions. ${ }^{38}$ The inversion of the burden of proof is widely used in both consumer and employment relations on grounds of the need to balance party powers through the principle of "low self-sufficiency" (hipossuficiência), which can be translated as a vulnerability for low economic power. ${ }^{39}$

Similarly, without being specifically defined, vulnerability is a cross-cutting issue in the Constitution of the Federal Republic of Brazil (Federal Constitution), by means of chapters or sections affording specific rights to protect minorities and marginalized individuals. Examples of this are indigenous people in Chapter II "On indigenous People," articles 231-32 and young and older persons in Chapter I, "On Family, Children, Adolescents, Young Persons, and Elderlies" articles 226-33. Second, some federal legislation entirely concerns groups considered underprivileged. This can be seen in the Children and Adolescents Statute, the People with Disabilities Statute, the Youth Statute, the Elder Persons Statute, the Indigenous Person Statute, the Racial Equality Statute, and the Inclusion of People with Disabilities Brazilian Act. ${ }^{40}$

Given that the notion of vulnerability indirectly pervades groups under special protection by law, the Brazilian framework has some resemblance to a "catalog approach" and which the vulnerable depends on being referenced in legislation tied to a set of rights. In some circumstances, the legislation makes very specific concessions or adaptations of public services for populations deemed vulnerable - such as waiving documents for access to social benefits-but that is not used to assess the nature or effect of policies on disadvantaged populations more broadly and serve as a short-term solution. ${ }^{41}$

As there is no general principle of vulnerability, public health responses needed to incorporate specific provisions for vulnerable groups. In April 2020, the National Congress enacted a special statute to individualize vulnerable people for the sole purpose of emergency income support during the pandemic. ${ }^{42}$ A problematic feature of numerous vulnerability provisions is the inconsistency with which the lower courts deal with the pandemic without a broader definition of vulnerability and its legal implication to rights and State conducts. Two similar situations involving vulnerability can have very different outcomes. In one decision, a prosecutor brought procedures

\footnotetext{
${ }^{35}$ Consumer relations are governed by The Consumer Protection and Defense Code. See Lei No. 8.078 de 11 de Setembro de 1990, art. VIII (Braz.) (Conferring to consumers "the facilitation of rights protection, including by inversion of burden of proof, in their favour . . . where, at the judge's discretion the allegation is credible, or should they (consumers) be regarded vulnerable under ordinary experience rules.).

${ }^{36}$ Código de Processo Penal [Penal Process Code] [C.P.P], art. 217-A, (Aug. 7, 2009) (Braz.) (as amended by Federal Act 12.015).

${ }^{37}$ Robert Fragale Filho, Resolving Disputes Over Employment Rights in Brazil, 34 ComPaR. LAB. L. Pol'y J. 929-48 (2012).

${ }^{38}$ Sergio Gamonal C. \& César F. Rosado Marzán, Protecting Workers as a Matter Principle: A South American View of US Work Law, 13 Wash. Univ. Glob. Stud. L. Rev. 2013-31, 620-22 (2014).

${ }^{39}$ Claudia Lima Marques \& Patricia Galindo da Fonseca, Consumer Protection in Brazil: The 2016 Report for the International Academy of Consumer Law, in ENFORCEMENT AND EFFECTIVENESS OF CONSUMER LAW 99-122, 102 (Hans-W. Micklitz \& Geneviève Saumier eds., 2018).

${ }^{40}$ The statutes referenced here are respectively: Lei No. 8.069, 13 de Julho de 1999 (Braz.); Lei No. 13.146, 6 de Julho de 2015 (Braz.); Lei No. 12.852, 5 de Agosto de 2013 (Braz.); Lei No. 6.001, 19 de Dezembro de 1973 (Braz.); Lei No. $12.288,20$ de Julho de 2010 (Braz.); Lei No. 13.146, 6 de Julho de 2015 (Braz.).

${ }^{41}$ Lei No. 13.982, 2 de Abril de 2020, art. 2 (9) II (Braz.).

${ }^{42} I d$. The law has been subsequently amended to encompass other groups or specific conditions-for instance, Lei No. 13.998, 14 de Maio de 2020 (Braz.), introduced the suspension of the student loan debits temporarily.
} 
to relocate fourteen elderly people that were in temporary facilities to a permanent one. ${ }^{43}$ In this appeal, the vulnerability situation of the group under care was regarded as serious enough to prevent any extension, despite the financial pressure with COVID-19. However, an order to implement local social services in other cases was deferred because that would place too much pressure on public finances owing to COVID-19. ${ }^{44}$

Thus, Brazilian law may adopt a catalog of vulnerable groups that is too inconsistent and may be discriminatory to those who are not classified as such because the provision is sparse and very specific, and the notion of vulnerability can be unevenly interpreted. From this, now we can move to the third form of vulnerability: The one described and litigated in courts. The following section will examine small case studies on the role played by the reported vulnerability experienced by claimants in lawsuits concerning populations negatively effected by Covid-19, with an identity dimension that vulnerability theory or a catalog approach cannot address alone.

\section{The Undeserving Vulnerable and the Growing Jurisprudence of COVID-19 in Brazil}

The litigation discussed in this section involves groups seeking to prove their vulnerability status to receive a policy compatible with their increased risks or to other vulnerable groups already recognized in law during the pandemic. By deliberate negligence, malpractice, or political will, the government made selective or incomplete interventions concerning vulnerabilities of parts of the population - as with indigenous people, black ethnic groups, workers, and prisoners, in the jurisprudence reviewed in this Article.

Because of their identity concern, the cases examined in this section will need nondiscrimination and substantive equality analysis in conjunction. They are "undeserving" vulnerable that lodge cases on the basis of the denial of their identity or social condition during the pandemic. As a result, it is difficult to dissociate vulnerability from a discriminatory policy in these cases and the remedy sought by some groups can evoke a sense of denied identity.

By not developing a general vulnerability doctrine or being constrained to legally recognized vulnerable groups, courts interpreted vulnerability as a matter of fact in COVID-19 decisions with little legal value on its own. The underserving vulnerable had to prove the special condition of vulnerability, even if they were part of a larger vulnerable group. For the undeserving vulnerable, a general principle of vulnerability can be useful, but it alone cannot engage with discriminatory elements originated from calculated identity attacks in Brazil—such as Bolsonaro's conservative politics or neoliberalist movements.

There is a common background in these cases. COVID-19 appeals moved to the highest courts in Brazil by requests of preventive measures as a duty to protect population health. At the time, vulnerability was not initially a question of access to drugs, inasmuch there was no confirmed treatment so far to cure the disease-and in the period of analysis there was no vaccine to prevent it. $^{45}$ Claims span wide-ranging policy areas—such as prison systems or work relations-and not just within health sectors.

Yet, it is worth noting that COVID-19 is not the first epidemic coming before judges in Brazil and recently the Superior Tribunal de Justiça has found a stronger duty to protect the population. In 2015, the STJ had to decide on whether a patient infected through blood transfusion in the early days of the HIV pandemic in the 1980s should be awarded damages. ${ }^{46}$ The Court rejected the

\footnotetext{
${ }^{43}$ TJ-SP; AI No. 2073789-03.2020.8.26.0000, Relator: Sá Moreira de Oliveira, 04.05.2020, 33 Câmara de Direito Privado, 04.05.2020 (Braz.).

${ }^{44}$ TJ-SP Ap. Civ. No. 1001131-03.2019.8.26.0042, Relator: Marcelo Semer, 29.05.2020, 10 Câmara de Direito Público, 29.05.2020 (Braz.).

${ }^{45}$ Jiancheng Zhang, Bing Xie, \& Kenji Hashimoto, Current Status of Potential Therapeutic Candidates for the COVID-19 Crisis, 87 Brain, Behavior, \& Immunity 59-73 (2020).

${ }^{46}$ STJ, Recurso Especial No. 1299900 RJ 2011/0302811-8, Relator: Humberto Martins, 03.03.2015, Segunda Turma, 13.03.2015 (Braz.).
} 
government's defense that no evidence of this type of transmission of HIV existed at the time. This is at minimum a contradiction in comparison to COVID-19. The legal reasoning with HIV was that the State had objective liability and employed the principle of precaution for all blood bank testing to potential risks in society, awarding damages independently of the level of scientific knowledge. While HIV testing was a matter of precaution in the case brought by a patient, the recent COVID-19 jurisprudence never treated State policies with this general standard and left certain discretion to the public administration.

With COVID-19, a broad duty to protect vulnerable people in every epidemiological aspect was rejected by the Supreme Court, even though the federal government has promoted policies that would be regarded as negligent with public health recommendations. In ADPF 672 and ADPF 676 , the Court did not recognize a failure to put in place protective measures for vulnerable people and only declared that even if federal action does not provide for higher protection in some matters, it is still open to States and municipalities authorities to use their complementary competence to implement extensive or even conflicting policies. ${ }^{47}$ The Justice Rapporteur Alexandre de Moraes observed that "in obedience of the separation of powers, the President of the Republic, as the driving force of the federal State in a presidential system" enjoys discretion to propose measures to contain the virus. Each federated state, however, has shared competence in the public health domain as well, in a described "cooperative federation." 48 Justice Moraes also highlighted that the Court could at some point discuss the constitutionality of any presidential act. In the decision, the STF did not use its attributions to consider whether the policies proposed by the federal government were a violation of the right to health, which was cited in the ruling only in passing.

As a common feature, the following judgments considered here also do not recognize a general precautionary principle to enforce preventive measures. There is neither a general vulnerability principle to justify State responsibility in the pandemic, as in a vulnerability theory, which would impose a duty to protect people of a range of potential risks in the pandemic. In this respect, vulnerability may be, even if explicitly stated by these judgments, only a factual element brought by claimants or noted by judges and not an articulated legal value. Litigants may engage partially with discrimination that increases their experienced vulnerability to assert their identity and social position.

\section{Prisoners and the Identity of the Inexcusable Offender}

In habeas corpus initiated by prisoners due to COVID-19, vulnerability was just a circumstance in the claims from the litigants' perspective. It was mentioned as a reason for temporary release in the pandemic, not as a ground of discrimination between prisoners who had the benefit or not. Public health authorities are well-informed of the overcrowded Brazilian penitentiary system, which makes inmates extremely predisposed to infectious diseases. Tuberculosis, for instance, is endemic to the criminal system, with a significant risk increase the longer individuals remain in custody. ${ }^{49}$ Despite this, the policy in Brazil was selective in terms of who could benefit from temporary conditional release, suggesting a category of undeserving vulnerable, who committed more serious crimes, with a criminal identity that outweighs human physical vulnerability.

At first, the deserving vulnerable in law had a narrow profile. In March 2020, the judiciary regulatory body in Brazil (National Council of Justice or NCJ) passed a recommendation for

\footnotetext{
${ }^{47}$ ADPF No. 672 / DF, Relator: Alexandre de Moraes, 08.04.2020 (Braz.); ADPF No. 676 / DF, 09.10.2020 (Braz.).

${ }^{48}$ ADPF No. 672 / DF Relator: Alexandre de Moraes, 08.04.2020 (Braz.).

${ }^{49}$ Andrea da Silva Santos, Carbone Dayse Sanchez Guimarães Paião, Renata Viebrantz, Enne Sgarbi, Everton Ferreira Lemos, Renato Fernando Cazanti, Marcos Massaki Ota, Alexandre Laranjeira Junior, José Victor Bortolotto Bampi, Vanessa Perreira Fayad Elias, Simone Simionatto, Ana Rita Coimbra Motta-Castro, Maurício Antonio Pompílio, Sandra Maria do Valle de Oliveira, Albert I. Ko, Jason R Andrews \& Julio Croda, Active and Latent Tuberculosis in Brazilian Correctional Facilities: A Cross-Sectional Study, 15 BMC INFECTIOUS DisEASES 24, 6-7 (2015).
} 
judges to place in house arrest or conditionally convict or suspect persons on remand who could be released on bail, but remained in custody for inability to meet this cost. ${ }^{50}$ The judicial administration guidance also provided for the situation of children and young persons in young offenders institutions, pregnant women, and other people under custody falling into a vulnerable group, such as indigenous people and individuals with chronic conditions. ${ }^{51}$ The recommendation was revised after six months to become even more restricted. It set out clearly that the leave should not apply for persons accused of violent crimes, corruption, domestic violence, or involved in criminal organizations, deepening the idea that certain types of criminals do not deserve being protected from COVID-19.52

The recommendation to judges to authorize home arrest in specific circumstances has not been effective, as some State Courts did not conform to the guidelines straightway. In the wake of the Council recommendation, several detainees and sentenced prisoners lodged applications for revision of their arrest - through writs of habeas corpus. In a sample of 307 cases from the State Court of São Paulo, only four recognized the actual vulnerability of detainees or prisoners, demonstrating the resistance of the judges to follow the recommendation. ${ }^{53}$ In lower courts, many appeals were dismissed, bringing the matter to the STJ to review the decision against federal legislation.

There was a controversy of the status of this recommendation and many judges preferred to ignore it and use their own discretion to assess relaxing prison regimes. Most likely, appeals will not stay in the lower courts and the question of prisoner vulnerability under the pandemic will inevitably open the way for further jurisprudence developments. In October 2020, a collective habeas corpus writ filed by public defenders representing several inmates was decided in the case of HC 56893/ES. The justices found that the NCJ recommendations are to be complied by judges, as not releasing prisoners incapable of affording the costs would be not proportionate. This decision was made binding on all lower courts and a notification was sent to all judges so prisoners in that category do not remain in custody. Justice Sebastião Reis Junior underlined that there is "stark supporting evidence" of "higher vulnerability" in prison settings and other agglomerations, such as in favelas, whose inhabitants "reveal to be more subject to infectious, despite protective equipment." 54

Yet, the exclusion of defendants for more serious crimes in the recommendations makes their vulnerability status regarded as less relevant than the gravity of their offenses-if the offender does not pose a substantial risk to society such as with a small-time drug dealer, it can be argued that it would not be fair to incarcerate someone from a risk group only because the defendant is more "criminally reprehensible." As it stands, the guideline is not formulated to measure the real risk for society individually but rather using certain offenses in the abstract. For instance, a seventy-eight year old former Congressmen died in prison from a COVID-19 infection while serving his sentence for corruption. ${ }^{55}$

It seems that the criminal identity of certain prisoners is more relevant than their vulnerable condition. The president of the STJ denied a collective writ of habeas corpus requesting house arrest for all prisoners with pre-existing health risks for COVID-19. ${ }^{56}$ Justice João Otávio de Noronha took the view that the risk assessment should be made individually for each case, which

\footnotetext{
${ }^{50}$ Conselho Nacional de Justiça, Recommendation No. 62, 17 de Março de 2020, amended by Recommendation No. 78, 15 de Setembro de 2020; Recommendation No. 68, 17 de Juno de 2020 (Braz.).

${ }^{51}$ Conselho Nacional de Justiça, Recommendation No. 62, Art. 2, 17 de Março de 2020 (Braz.).

${ }^{52}$ Conselho Nacional de Justiça, Recommendation No. 78, Art. 1, 15 de Setembro de 2020 (Braz.).

${ }^{53}$ Natalia Pires de Vasconcelos, Maíra Rocha Machado \& Daniel Wang, COVID-19 in Prisons: A Study of Habeas Corpus Decisions by the São Paulo Court of Justice, Revista Administracao Pública 12-13 (2020).

${ }^{54}$ STJ, HC 56893/ES, 01.04.2020 (Braz.).

${ }^{55}$ Agencia Brasil, Morre de Covid-19 o Ex-Deputado Nelson Meurer, $1^{\circ}$ Ccondenado na Lava Jato, UOL, July 16, 2020, https:// noticias.uol.com.br/politica/ultimas-noticias/2020/07/12/morre-de-covid-19-o-ex-deputado-nelson-meurer-1-condenado-nalava-jato.htm?cmpid=copiaecola (last visited Oct 16, 2020).

${ }^{56}$ STJ, HCNo. 596.189 DF 2020/0169244-4, Relator: João Otávio de Noronha, 23.07.2020, 04.08.2020 (Braz.).
} 
would prevent a general release order. ${ }^{57}$ Conversely, this reasoning did not apply to the regulations that prohibit certain offenders of conditional release due to a blanket list of crimes regarded more serious or indicating a higher risk to society.

In the meantime, STF did not interfere with these treatment disparities between criminal offenses. The situation of prisoners could have been decided in a major judgment within the implementation procedures of ADPF 347, which in 2015 declared that Brazil remains in an "unconstitutional state of affairs," a term imported from the Constitutional Court of Colombia to denominate the dehumanizing treatment across the whole penitentiary system. ${ }^{58}$ The case received a new petition for interim measures in view of the pandemic and restated some of the measures that were recognized as urgent in 2015 given the overcrowding and poor conditions of prisons in Brazil. In March 2020, Justice Marco Aurelio granted a list of measures to protect all vulnerable groups from the outbreak, but the decision was overruled mainly on procedural grounds by the Court in a session one day later. ${ }^{59}$ In another procedure, however, the presidential veto to a norm making obligatory wearing masks in prisons was recognized as unconstitutional. ${ }^{60}$ Overall, the judicial system in Brazil maintained a distinction between deserving vulnerable prisoners and non-deserving, based on the offense committed and not their degree of vulnerability.

\section{Indigenous People and Cultural-Territorial Identity}

Indigenous populations had great success in asserting their vulnerability in courts during the pandemic to defend their cultural identity and collective interests. These Brazilian peoples comprise nearly 305 ethnic groups of 907,000 self-declared indigenous individuals in villages and urban centers speaking 207 languages. ${ }^{61}$ It is known that vulnerability among this population does not only stem from impoverishment and may be caused by lower immunity to urban infectious diseases, cultural habits, and the increased presence of non-indigenous people invading their territory. ${ }^{62}$ Following the outbreak, many tribes took refuge deep into the jungle, in a recreation of the colonization-time exodus when the Europeans slaughtered up to ninety percent of tribes by importing foreign diseases. ${ }^{63}$

Their vulnerability, therefore, is intrinsic to their historical identity and territorial roots, rendering a general principle of vulnerability less appropriate. Such identity was under siege with Bolsonaro, who defended Brazilian sovereignty over natural resources while being lenient with deforestation, landgrabbers, and wildfires in indigenous territories. ${ }^{64}$ Since the Bolsonaro election, the government advocated miscegenation as a natural progression and cast doubt on the justification of indigenous protected areas for the small size of their population. ${ }^{65}$ In 2019, the Ministry of Health dismantled the public health services specialized for indigenous people, and in the pandemic, the government carried on with the discourse of "one single Brazilian" to offer the same

\footnotetext{
${ }^{57} I d$.

${ }^{58}$ STF, ADPF 347 MC/DF, Relator: Marco Aurélio, 09.09.2015 (Braz.).

${ }^{59}$ STF, ADPF 347, Relator: Marco Aurélio, 18.03.2020 (Braz.).

${ }^{60}$ STF, ADPF 714, Relator: Gilmar Mendes, 03.08.2020 (Braz.).

${ }^{61}$ Data informed to the STF by the Indigenous People Coalition of Brazil (APIB, in Portuguese), https://www.jota.info/wpcontent/uploads/2020/06/adpf-apib-compressed.pdf (last accessed Oct. 10, 2020).

${ }^{62}$ Lucas Ferrante \& Philip M. Fearnside, Protect Indigenous Peoples from COVID-19, 368 SCI. 251.1-251, 251 (2020).

${ }^{63}$ Philippe Charlier \& Leandro Varison, Is COVID-19 Being Used as a Weapon Against Indigenous Peoples in Brazil?, 396 THE LANCET 1069-70 (2020).

${ }^{64}$ Pedro Rapozo, Necropolitics, State of Exception, and Violence Against Indigenous People in the Amazon Region During the Bolsonaro Administration, 15 Braz. Pol. SCI. Rev. 5, 5-8 (2021); Sufyan Droubi \& Raphael J. Heffron, Politics' Continued Erosion of Sustainable Development for Brazil's Indigenous Peoples, 5 PERIPHERIES J. 5 (2020).

${ }^{65}$ Daniel Angyalossy Alfonso, Bolsonaro's Take on the 'Absence of Racism' in Brazil, 61 RACE \& Class 33, 34-35 (2020).
} 
healthcare to the whole population. ${ }^{66}$ Bolsonaro's offensive has been denounced by International Criminal Court as a form of genocide, before and after the pandemic. Politically, the rejection of indigenous identity through their territory has aligned the military, evangelical parties, and the government to prevent their land demarcation and defund indigenous protection agencies and programs. ${ }^{67}$

On one hand, the vulnerability of indigenous people in the pandemic was in principle recognized by law. Listening to the public demands of various indigenous communities, the Brazilian Congress passed Law 14.021 in July 2020. The act establishes the "Emergency Plan for the response to the Covid-19 in Indigenous Territories" and sets out points of action for the government, such as health surveillance. ${ }^{68}$ The legal text described the indigenous people as of "extreme vulnerability," but the Bolsonaro administration in practice did little to ensure indigenous wellbeing. ${ }^{69}$

On the other hand, vulnerability was the central circumstance in denouncing Bolsonaro's hate speech before the STF in a constitutional complaint of Brazil's Indigenous People Articulation (APIB). The constitutional norms allegedly violated were the right to health, right to life, and the right of cultural identity, but the term vulnerability was namely described by the claimants in various contexts: Epidemiologic, demographic, territorial, and political. ${ }^{70}$ Higher mortality and epidemiological vulnerability were summarily dismissed by the government, while indigenous representation recalled that data was incomplete as deaths in urban areas remained underreported.

Moreover, even though the government had announced a plan explicitly involving indigenous people as a vulnerable group, the measures approved were not accepted as too vague and without indigenous participation. The initial motion reported a list of omissions and detrimental policies, namely: a) Absence of any closure of indigenous territories to external population and tolerance of invaders of forest conservations, b) ill-managed intervention of health services contributing to the spread of the virus through personnel, and c) political decision of the government not to make available specialized health services to indigenous people living in urban areas and only report data on Covid-19 cases with indigenous people in native territory. ${ }^{71}$

Some indigenous persons, in many circumstances, were undeservingly vulnerable for not being the classic primitive man, as the claimants argued that there was territorial discrimination outside the village. Not much was said in the decision, though, about vulnerability as a legal principle, and Justice Barros, in the injunction, considered only the material aspects of the higher risk of indigenous vulnerability, including their community traditions and lack of political representation.

Instead, Justice Barroso, adopted two other principles to grant an interim order for the comprehensive plan: The precautionary principle — normally associated with environmental law_and the principle of participation. The second principle confirms the identity essence of vulnerability, as per the International Labour Organization Convention $169 .{ }^{72}$ Those norms ensure that indigenous people participate in all affairs directly affecting them as a right of self-determination and cultural identity. ${ }^{73}$

\footnotetext{
${ }^{66}$ Maurício Polidoro, Francisco de Assis Mendonça, Stela Nazareth Meneghel, Alan Alves-Brito, Marcelo Gonçalves, Fernanda Bairros, \& Daniel Canavese, Territories Under Siege: Risks of the Decimation of Indigenous and Quilombolas Peoples in the Context of COVID-19 in South Brazil, J. Racial Ethnic Health Disparities 5 (2020), http://link.springer. com/10.1007/s40615-020-00868-7 (last visited Oct. 28, 2020).

${ }^{67}$ François-Michel Le Tourneau, Bolsonaro Government Against Indigenous Peoples: Constitutional Guarantees Put to the Test, Confins Revue Franco-Brésilienne de Géographie Revista Franco-Brasileira de Geografia, 3-10 (2019).

${ }^{68}$ Lei No. 14.021, 2020.

${ }^{69} \mathrm{Id}$. at art. 2.

${ }^{70}$ STF, ADPF 709 MC / DF, Relator: Roberto Barroso, 05.08.2020, paras. 75-86, n. 23 (Braz.).

${ }^{71}$ Id. at n. 20

${ }^{72}$ ILO Convention No. 169, Concerning Indigenous and Tribal Peoples, arts. 2 (1); 4 (1) (2), 5 and 7 (Sept. 5, 1991).

${ }^{73} I d$., at art. $2.2 \mathrm{~b}$.
} 
One interesting aspect of this lawsuit is that the petitioners overcome a very high procedural requirement to allow the question to be put before the Court. The judicial mechanism proposed was a concentrated control of constitutionality via a legal action called "procedure for non-compliance of fundamental principle" (ADPF, in the Portuguese acronym) admissible only if no other procedure is available in all domestic courts. ${ }^{74}$ The petitioners maintained that the situation was so devastating and spanning multiple institutions that there would be otherwise no form to refer to the Court and manage altogether all violations. In an oral argumentation before the Court, the lawyer Eloy Terena, an indigenous Brazilian, said it is not an overstatement to call these events a "genocide."75

Agreeing with the argument that structural failures had no other form of remedy, Justice Barroso then granted a preventive measure in a single-judge interim decision. In many aspects, the argued violations of indigenous rights were made by ill-planning from the government. However, this was equally a consequence of the hostile environment of the current presidency and the attempts to undermine the indigenous identity beyond their official territories-not reporting deaths nor providing services outside indigenous communities. It was noted that the President made serious declarations to the press about his intention of "eliminating all indigenous territories" after he took office and "give rifles and firearms to all farmers."76 Barroso found as well that despite numerous actions from the government, there was no coordinated and efficacious plan to address the particular risks of indigenous populations.

The interim injunction was granted in two parts, setting out policies that should be negotiated under the supervision of the Court. One part is concerned with a plan for "isolated or recently contacted indigenous people involving sanitary cordons" and a situation room to manage the respective measures composed by executive officials, federal public defenders, and representatives of the communities. ${ }^{77}$ As to measures to the whole indigenous population, the Court determined a general plan, with an immediate system to prevent invaders in their territories and access to appropriate health care services to indigenous in non-registered territories or residing outside villages.

While the closure of the most endangered indigenous communities made progress, the subsequent general plan proposed by the government to contain the infection was not well received. Civil organizations listed areas where the spread was more likely to happen and requested a priority program to the most vulnerable regions. ${ }^{78}$ NGOs that participated in the process as amicus curie raised several objections to the plan submitted by the government to the Court for its narrow details and progress from the previous version. ${ }^{79}$ In October, Justice Barroso dismissed the approval of the general plan made and found the new document wanting in indicators and chronograms necessary for the Court assessment of the implementation of the measures. ${ }^{80}$

Concluding, the government has made some additional efforts to address the discrimination against indigenous between different classes of undeserving and deserving vulnerable as to their location-non-registered territory or urban areas-or about the services provided to the population in other regions. The recently formed institutional dialogue between the Executive and Judiciary

\footnotetext{
${ }^{74}$ STF, ADPF 709 MC / DF, Relator: Roberto Barroso, 05.08.2020, paras. 1-5 (Braz.).

${ }^{75}$ Essa ação é a voz dos povos indígenas no STF, Aug. 3, 2020, https://apiboficial.org/2020/08/03/essa-acao-e-a-voz-dospovos-indigenas-no-stf/ (last visited Oct. 30, 2020).

${ }^{76}$ STF, ADPF 709 MC / DF, Relator: Roberto Barroso, 05.08.2020, paras. 62-65 (Braz.).

${ }^{77} I d$.

${ }^{78}$ STF, ADPF 709 MC / DF, Relator: Roberto Barroso, 21.10.2020 (Braz.).

${ }^{79} I d$. Among the other reasons for the dispute with the government reaction were that: a) The plan only continued with the activities already foreseen and did not expand the intervention, and b) measures were generic and without indicators for monitoring performance, particularly by not giving details of aims and actions for controlling invaders, closing borders, providing food, other supplies, and a method to ensure indigenous voice in any decision.

${ }^{80}$ STF, ADPF 709 MC / DF, Relator: Roberto Barroso, 21.10.2020 (Braz.).
} 
so far has not been proved to be an immediately successful mechanism for indigenous communities, as the violation reports have not ceased yet.

\section{Afro-descendant Communities, Identity, and Racial Discrimination}

While indigenous people had, at the very least, some focused programs from the government, the situation of another ethnic and cultural group was considerably more overlooked. Quilombos are a historical Brazilian community originally built by runaway slaves and their descendants in the years of Portuguese colonial forced labor from the African trade. ${ }^{81}$ The status of quilombolas (members of these traditional Afro-Brazilian settlements) is constitutionally recognized ${ }^{82}$ Still, access to health services for these Afro-descendants is notoriously inadequate and their health quality inferior to other populations, either by lack of adequate health services, sanitation, or poverty. ${ }^{83}$

At the same time, the special requirements of vulnerability in the national policy against COVID-19 for indigenous people were not extended to quilombos after the judgment of ADPF 709, in which the black settlements were not part of the lawsuit. While both groups share the same territorial threats and comparable risks-especially in the Southern areas—-national policies did not take into account targeted programs to quilombola-indigenous people had initially a more thorough action plan. ${ }^{84}$ The opportunity to revise the original plan to address effectively the quilombola situation was not used in the new plan and the STF has not specified the implications of this ruling to these people as they did not have legal standing. Again, a civil representation (CONAQ) — a quilombola organization — and leftist political parties filed another case with the court to declare the unconstitutionality of the government measures for not tailoring protective provisions to this cultural group. ${ }^{85}$ The fact that a similar claim that of the indigenous people needs to be lodged with the Courts makes more evident the variance in treatment to certain populations-technically, they do not cooperate, as they had independent lawsuits.

In their submission to the Court, the quilombola organization explicitly framed their problem as negligence towards various domains of vulnerabilities - territorial, socio-economic, sanitary, health, and structural racism. ${ }^{86}$ Because of institutional racism, quilombolas brought to the case more discriminatory elements and attacks on their identity made during Bolsonaro's government. They reported some of Bolsonaro's racist quotes, including his plan to integrate black communities, abolish black settlements, and the opinion that "racisms in Brazil is a rare thing." 87

However, the ability of quilombolas to bring awareness to their vulnerability was relatively slower and the Constitutional Court only effectively responded to their motion in February of $2021 .{ }^{88}$ The Court ordered a contingency plan for the petitioners - in a decision similar to the indigenous complaints-but also determined the suspension of all repossession orders involved these communities. The decision had a dissenting vote of Justice Nunes Marques, who found that

\footnotetext{
${ }^{81}$ Roseane do Socorro Gonçalves Viana \& Anne C. Bellows, 'Teacher, We are Hungry.' The Violation of Quilombolas Students' Right to Adequate Food, a Case Study, 18 InT. J. Hum. Rights 774-94, 776-77 (2014).

${ }^{82}$ See Constitutional Transitory Provisional Act, art. 68 (as revised by Decree 4887/2003) (stating that Quilombolas are "ethnic-racial groups, as per the criteria of self-declaration, with their own historical development, enjoying specific territorial relationships, with the presumption of black ancestry related to the resistance to suffered historical oppression.").

${ }^{83}$ Daniel Antunes Freitas, Antonio Diaz Caballero, Amaro Sergio Marques, Clara Inés Vergara Hernández \& Stéffany Lara Nunes Oliveira Antunes, Saúde e Comunidades Quilombolas: Uma Revisão da Literatura, 13 Rev. CEFAC 937943 (2011).

${ }^{84}$ Polidoro et. al., supra note 67 , at 6-7.

${ }^{85} \mathrm{See}$ CONAQ, Arguição De Descumprimento De Preceito Fundamental Com Pedido De Medida Liminar (filed constitutional complaint), https://terradedireitos.org.br/uploads/arquivos/ADPF-QUILOMBOLA-Assinado.pdf, (last accessed Oct. 10, 2020).

${ }^{86} I d$. (Noting that $57 \%$ of the Quilombolas' villages have no respirators, and $89 \%$ of their residence municipalities have no intensive care unit.)

${ }^{87} \mathrm{Id}$.

${ }^{88}$ STF, ADPF 742, 24.02.2021 (Braz.).
} 
"it is understandable that the who population is apprehensive, but the virus does not recognize ethnic distinction." ${ }^{\prime \prime}$ This reveals that the condition of vulnerability requiring specific measures is not a standard interpretation and Courts can still be deferential to how States prioritize public health measures among vulnerable groups.

\section{Workers and Employment Relationship Discrimination}

COVID-19 has deepened the effect of new pressures on the working class in Brazil. The shifting forms of vulnerability in labor relations in Brazil serve to illustrate that a broader principle of vulnerability might be key to address claims from workers experiencing new sources of risk and economic instability. But still, there are forms of identity vulnerability that require attention. Work-related violation once concentrated in some activities, such as in mining and natural resources extraction, now are found increasingly in the urban market, with the gig economy, casual agreements, and outsourcing formed by white men and women, who lost their identity as employees with legal guarantees. ${ }^{90}$

After COVID-19, new vulnerable groups joined old ones, such as domestic workers, an occupation which has never enjoyed equal protection in the Brazilian law. ${ }^{91}$ Another disproportionally affected group was the health workers, serving as the "canaries in the mine" in badly organized community operations and low medical infrastructure. ${ }^{92}$ Moreover, workers, in general, had to adapt to an economic recession, and a reform agenda was set afoot for the sake of business growth by less individual rights and direct employer negotiation. ${ }^{93}$

The government stance towards labor liberalization — which had already destabilized unionswas repeated with COVID-19. ${ }^{94}$ In an emergency decree to regulate labor relations in the pandemic, converted in July in Act 14.020, the legal prohibition of salary reduction has been relaxed to sustain the economy. ${ }^{95}$ A complaint was submitted to argue that the unconstitutionality of this measure by the STF only suspended the effect of these norms to ensure that workplace inspections stay in operation and repeal a liability waiver for occupational diseases contracted in the pandemic. $^{96}$ The Court did not specifically declare that COVID-19 infections in the work environment would constitute a work-related disease and it remains unclear whether employees would be able to produce evidence of contracting the virus in that manner.

Against this background, among all workers, the category of underserving vulnerable rests with those considered self-employed in the gig economy, to whom health and safety measures do not apply. Further policies were needed for gig workers after COVID-19, but their condition fell completely outside the scope of the law in a ruling preventing an app-based independent worker from employment rights. In February, 2020, the TST held that employment rights do not apply to Uber

\footnotetext{
${ }^{89} \mathrm{Id}$.

${ }^{90}$ Salo V. Coslovsky, Flying Under the Radar? The State and the Enforcement of Labour Laws in Brazil, 42 OXFORD DEV. STUD. 190-216, 195-204 (2014).

${ }^{91}$ Ana Virginia Moreira Gomes \& Patrícia Tuma Martins Bertolin, Regulatory Challenges of Domestic Work: The Case of Brazil, 27 InT'L J. COMPar. LAB. L. \& INDUS. Rel. 221 (2011).

${ }^{92}$ Gabriela Lotta, Clare Wenham, João Nunes \& Denise Nacif Pimenta, Community Health Workers Reveal COVID-19 Disaster in Brazil, 396 THe LANCET 365-66 (2020).

${ }^{93}$ Amauri Cesar Alves \& Thiago Henrique Lopes de Castro, Labor Reform and Movements of Restructuring, Precarisation and Reduction of Employment Law in Brazil, 4 J. OF Soc. \& LAB. ReL. 130 (2018).

${ }^{94}$ Elizabeth McKenna, Taxes and Tithes: The Organizational Foundations of Bolsonarismo, INT'L Socio. 22, 614-16 (2020).

${ }^{95}$ Lei No. 14.020, 6 de Julho de 2020, art. 3 (Braz.) (authorizing employers to reduce working hours with proportionate deduction of payment and suspension of employment during the pandemic.)

${ }^{96}$ The original statute was an emergency decree (medida provisória), see MP 927/2020, 22 de Março de 2020 (Braz.). Opposition parties and a national industrial workers union sought the declaration of unconstitutionality of the whole new regulation in a series of lawsuits: ADI 6432, ADI 6344, ADI 6346, ADI 6348, ADI 6349, ADI 6352 and ADI 6354.
} 
drivers, days before the pandemic unfolded. ${ }^{97}$ Eight months after that, the Court heard another case from Uber and held the company had no obligation to provide personal protective equipment (PPE) and pay minimum wage to the drives at disposal but without passengers in the State of Ceará. ${ }^{98}$

The interim injunction overturned by TST was an issue in a lawsuit from a drivers' union of the State of Ceará and the opinion of the first-tier judge Germano Siqueira was much more socially responsive. He wrote: "Contracts in the course of this pandemic, should be interpreted in light of the social interest and the most elevated constitutional principles, that point toward the social end they boast." 99

These judgments are but only a few examples of the vulnerability repercussions in working relations in Brazil during the pandemic and the legal effect of vulnerability over employment contracts. Since the onset of the pandemic, the number of labor procedures openly connected with the crisis was 133.954 cases with $\$ 14.24$ billion in claims value, an average of $\$ 106,288$ per lawsuit. ${ }^{100}$

The full extension of the repercussions of COVID-19 in worker rights is far from being settled case-law and merits more careful analysis to determine the types of claims brought by employees. Therefore, TST is bound to revisit this matter in future appeals, though it has already indicated that will be differential to new liberal work relations. ${ }^{101}$

\section{Conclusions}

I have presented in this Article rights-based litigation during the Covid-19 crisis in Brazil where identity and vulnerability are interconnected. Vulnerability has different usages and conceptualizations across academia, law, and litigation practice in Brazil. Traditional vulnerability theory emphasizes breaking with identities and seeking an overall legal principle that underscores a responsive State. Law in Brazil does accept some identity classification, but by setting out provisions for specified vulnerable groups, it is too narrow to understand nuances and variations of new and non-traditional forms of vulnerability and identity conflicts-for example, employees vs. gig workers. I have shown that litigants affected by COVID-19 have referred to notions of vulnerability such as the epidemiological, cultural, and territorial vulnerability of quilombolas and indigenous people. However, that has an element of identity that either challenges some discrimination by law or reclaims the status of a person as part of a protected vulnerable group. To summarize, both an approach of vulnerable groups by law and Fineman's theory of vulnerability are insufficient to address racial and socio-cultural disparities grounded in identity and social class conflicts raised by rights-holders and social movements, particularly in the context of a global health emergency.

An important goal is to work towards a composite vulnerability principle, with targeted universalism: Vulnerability establishes State duties to all persons, but cannot dismiss identifiable groups or identity-based discrimination as its root cause. ${ }^{102} \mathrm{My}$ understanding is that vulnerability cannot be dissociated from identity and may be recognized through vulnerable groups in law, but must allow some flexibility for new groups, in special in unpredictable circumstances such as COVID-19 or after identity attacks by extremist political groups. New categories of vulnerable

\footnotetext{
${ }^{97}$ TST, Recurso de Revista No. 1000123-89.2017.5.02.0038, Relator: Breno Medeiros, 05.02.2020, 5 Turma, 07.02.2020 (Braz.) (Finding that workers should be considered self-employed in services hired through Uber as most of the earning - upwards of eighty percent-is transferred to the driver).

${ }^{98}$ TST, No. 1001466-89.2020.5.00.0000, Relator: Douglas Alencar Rodrigues, 05.10.2020 (Braz.).

${ }^{99}$ TRT-7, 295-13.2020.5.07.0003, 14.04.2020, 3 Vara do Trabalho de Fortaleza (Braz.).

${ }^{100}$ Termômetro COVID-19 NA JustiçA DO TRABALHO, https://www.datalawyer.com.br/dados-covid-19-justica-trabalhista (last visited Oct. 2020) (the tool tracks the text of all complaints submitted electronically to the courts and identifies key words related to COVID-19).

${ }^{101}$ The first ruling against Uber was confirmed by other decisions in similar claims in September 2020.

${ }^{102}$ Angela P. Harris \& Aysha Pamukcu, The Civil Rights of Health: A New Approach to Challenging Structural Inequality, 67 UCLA L. REV. 758, 829-31 (2020).
} 
groups may emerge that confer special status and additional State response, but some cases of vulnerability may be the direct result of State policies delegitimizing one's identity. The questions that Brazilian courts should tackle include what the elements of a thorough vulnerability analysis are, the prerogatives it confers in a public health crisis to some individuals, or in which conditions it can be used in a public crisis against other interests and pre-existing rights violations. Other paths of analysis are whether a precautionary principle could be articulated alongside vulnerability and to what extent vulnerability increases or entails precautions in public health against uncertainties or low-quality evidence.

There is still room for further research on the effectiveness of those decisions in the case studies presented and investigation of other identities discriminated against by the Brazilian government in this period. The cases referred to in this study in relation to indigenous people and quilombolas are still pending or in the implementation phase, with no evaluation of the effect on public health outcomes. Gig workers are also still challenging their legal status and people in custody will continue lodging appeals with the higher courts with the aid of public defenders and individual lawyers.

The existence of parallel forms of understanding and applying vulnerability may cause uncertainty and we do not know yet whether judges will start giving legal meaning to the way vulnerability language is used by litigants. We might be at the outset of a broader "vernacularization" of vulnerability between claimants and legislators. ${ }^{103}$ It has been shown that litigants may resort to the language of vulnerability with different meanings from vulnerability theory or what is prescribed in law, based on their identity. Recent jurisprudence of COVID-19 may be referred to as vulnerability with relative authority in some decisions but no legal implications on its own. As courts in Brazil have not given the clarity of legal implications of vulnerability, this notion can be unevenly interpreted and create discrepancies on how it is used in different areas of law. It is necessary to conduct more closer studies of how vulnerability language is used in other contexts by litigants and compare the success of claiming vulnerability in different groups and its power as a complementary tool to human rights or constitutional rights language.

Also, scholarship must determine how to ensure some equality among the rights conferred to special groups after vulnerability is invoked. The Brazilian legal system has different provisions concerning each vulnerable group-vulnerable groups litigating against the State have a higher burden of proof than consumers against companies. We know, for instance, that now entrepreneurs and company owners have their vulnerability established in the law in Brazil. Comparing the outcomes of this legislation to traditionally vulnerable groups litigation deserves further attention as well.

As vulnerability is also a discourse, an argument or term raised by some groups in legal procedures and part of their legal strategy, it may not be used effectively in all possible cases and have different effects on its users according to their awareness and political force. Domestic workers, for instance, have proven to be extremely vulnerable - including with earlier deaths - but have never pressed with a constitutional vulnerability claim in higher courts. ${ }^{104}$ This area requires careful and in-depth research to understand the conditions of legal mobilization, including through legal consciousness of vulnerability as a platform for litigation and the suitable redress when identity is at the heart of vulnerability.

\footnotetext{
${ }^{103}$ See e.g., Sally Engle Merry, Transnational Human Rights and Local Activism: Mapping the Middle, 108 AM. ANTHROPOLOGIST 38-51 (2006).

${ }^{104}$ Louisa Acciari, Juana del Carmen Britez \& Andrea del Carmen Morales Pérez, Right to Health, Right to Live: Domestic Workers Facing the COVID-19 Crisis in Latin America, 29 GENDER \& DEV. 11, 27 (2021).
}

Cite this article: Bottini Filho L (2021). Covid-19 Through Brazilian Courts: The Deserving and the Undeserving Vulnerable. German Law Journal 22, 1098-1114. https://doi.org/10.1017/glj.2021.55 